Article

\title{
Effect of Molybdenum on the Activity Temperature Enlarging of Mn-Based Catalyst for Mercury Oxidation
}

\author{
Bo Zhao ${ }^{1,2}$, Xiaojiong Zhao ${ }^{2}$, Yangshuo Liang ${ }^{1}$, Yu Wang ${ }^{1}$, Linbo Qin ${ }^{1, *}$ and Wangsheng Chen ${ }^{1}$ \\ 1 Hubei Key Laboratory for Efficient Utilization and Agglomeration of Metallurgic Mineral Resources, \\ Wuhan 430081, China; zhaobo87@wust.edu.cn (B.Z.); liangyangshuo@126.com (Y.L.); \\ yuwang@wust.edu.cn (Y.W.); chenwangsheng@wust.edu.cn (W.C.) \\ 2 Industrial Safety Engineering Technology Research Center of Hubei Province, \\ Wuhan University of Science and Technology, Wuhan 430081, China; jiongwust@163.com \\ * Correspondence: qinlinbo@wust.edu.cn
}

Received: 11 January 2020; Accepted: 20 January 2020; Published: 22 January 2020

\begin{abstract}
The} \mathrm{MnO}_{2} / \mathrm{TiO}_{2}\left(\mathrm{TM}_{5}\right)$ catalyst modified by molybdenum was used for mercury oxidation at different temperatures in a fixed-bed reactor. The addition of molybdenum into $\mathrm{TM}_{5}$ was identified as significantly enlarging the optimal temperature range for mercury oxidation. The optimal mercury oxidation temperature of $\mathrm{TM}_{5}$ was only $200{ }^{\circ} \mathrm{C}$, with an oxidation efficiency of $95 \%$. However, the mercury oxidation efficiency of $\mathrm{TM}_{5}$ was lower than $60 \%$ at other temperatures. As for $\mathrm{MnO}_{2}-\mathrm{MoO}_{3} / \mathrm{TiO}_{2}\left(\mathrm{TM}_{5} \mathrm{Mo}_{5}\right)$, the mercury oxidation efficiency was above $80 \%$ at $200-350{ }^{\circ} \mathrm{C}$. In particular at $250{ }^{\circ} \mathrm{C}$, the mercury oxidation efficiency of $\mathrm{TM}_{5} \mathrm{Mo}_{5}$ was over $93 \%$. Otherwise, the gaseous $\mathrm{O}_{2}$, which could supplement the lattice oxygen in the catalytic reaction, played an important role in the process of mercury oxidation over $\mathrm{TM}_{5} \mathrm{Mo}_{5}$. The results of X-ray photoelectron spectroscopy (XPS) suggested that mercury oxidized by $\mathrm{O}_{2}$ over $\mathrm{TM}_{5} \mathrm{Mo}_{5}$ followed the Mars-Maessen mechanism.
\end{abstract}

Keywords: mercury oxidation; $\mathrm{MnO}_{2}-\mathrm{MoO}_{3} / \mathrm{TiO}_{2}$; temperature; mars-maessen mechanism

\section{Introduction}

Coal-fired power plants are among the largest mercury emission sources from anthropogenic activities [1]. Because of its toxicity to the environment and human health, mercury emission from coal-fired power plants has been strictly limited in the United States [2]. In China, a mercury emission limitation of $0.03 \mathrm{mg} / \mathrm{m}^{3}$ was announced in the Emission Standard of Air Pollutants for Thermal Power Plants (GB13223-2011). Additionally, the Chinese government deposited the ratification of the Minamata Convention on Mercury, and became the 30th country of the Convention on August 31st, 2016. This means that the limit of mercury emission from coal-fired power plants in China will be stricter [3].

Mercury exists as three forms in coal combustion flue gas: elemental mercury $\left(\mathrm{Hg}^{0}\right)$, oxidized mercury $\left(\mathrm{Hg}^{2+}\right)$, and particle-bound mercury $\left(\mathrm{Hg}^{\mathrm{p}}\right)$ [4]. $\mathrm{Hg}^{2+}$ and $\mathrm{Hg}^{\mathrm{p}}$ can be easily eliminated by wet flue gas desulphurization (WFGD) and electrostatic precipitator (ESP) [5], respectively. However, $\mathrm{Hg}^{0}$ is difficult to capture by existing air pollution control devices due to its water insolubility and volatility. In the past 20 years, the methods of mercury removal, such as adsorption by sorbents [6,7] and oxidization by oxidants [8] or catalysts $[9,10]$, have been widely investigated. Catalytic oxidation of $\mathrm{Hg}^{0}$ was in the spotlight when the selective catalytic reduction (SCR) system in coal-fired power plants was found to be beneficial for elemental mercury oxidation [11,12]. Hence, a variety of catalysts for mercury oxidation have been developed recently. Metal oxides, such as $\mathrm{V}_{2} \mathrm{O}_{5}[13,14], \mathrm{Fe}_{2} \mathrm{O}_{3}$ [15], $\mathrm{CeO}_{2}$ [16], $\mathrm{MnO}_{2}$ [17], $\mathrm{CuO}$ [18], etc., have been loaded as active ingredients on the catalysts for mercury 
oxidation. Peña et al. [19] found that the catalytic activity of the catalysts followed the sequence Mn > $\mathrm{Cu}>\mathrm{Cr}>\mathrm{Co}>\mathrm{Fe}>\mathrm{V}>\mathrm{Ni}$, which indicated that an Mn-based catalyst was an excellent choice for mercury oxidation. Ji et al. [20] reported that $\mathrm{MnO}_{2} / \mathrm{TiO}_{2}$ was available for $\mathrm{Hg}^{0}$ oxidation and $\mathrm{NO}$ reduction simultaneously at $200{ }^{\circ} \mathrm{C}$, with a mercury oxidation efficiency of $90 \%$ and NO conversion efficiency of $97 \%$. Wu et al. [21] indicated that Mn-based catalysts were beneficial for mercury oxidation, and elemental mercury removal efficiency follows the order $4 \% \mathrm{Mn} / \mathrm{MK} 10$ (montmorillonite K 10) $>4 \%$ $\mathrm{Mn} / \mathrm{SiO}_{2}>4 \% \mathrm{Mn} / \mathrm{TiO}_{2}>4 \% \mathrm{Mn} / \mathrm{Al}_{2} \mathrm{O}_{3}$. In particular for the $\mathrm{Mn} /$ montmorillonite $\mathrm{K} 10$, the mercury removal efficiency was greater than $90 \%$ [22]. However, mercury oxidation ability of $\mathrm{MnO}_{2} / \mathrm{TiO}_{2}$ was significantly restrained in the presence of $\mathrm{SO}_{2}$, and more than $80 \%$ of $\mathrm{Hg}^{0}$ escaped [20]. The optimal temperature of the Mn-based catalyst for mercury oxidation was always lower than $250{ }^{\circ} \mathrm{C}$, and the formation of $\mathrm{NH}_{4} \mathrm{HSO}_{4}$ was the main reason for the catalyst deactivation at low temperature [23]. One way to enhance mercury oxidation ability was to add various auxiliary metal components into the Mn-based catalyst and keep low-temperature activity. Ce [17,24,25], Fe [3,15], and Co [16] were extensively loaded into the Mn-based catalyst. Li et al. [19] reported that the Mn-Ce/Ti catalyst exhibited high mercury oxidation ability at $150-250{ }^{\circ} \mathrm{C}$. He et al. [25] stated that $6 \% \mathrm{Ce}-6 \% \mathrm{MnO} / \mathrm{Ti}-\mathrm{PILC}$ exhibited optimal mercury oxidation ability at $250{ }^{\circ} \mathrm{C}$, with a mercury oxidation efficiency of $72 \%$.

Another way to avoid $\mathrm{NH}_{4} \mathrm{HSO}_{4}$ being deposited on the catalyst was to enhance the activity temperature of the Mn-based catalyst for mercury oxidation. In general, less $\mathrm{NH}_{4} \mathrm{HSO}_{4}$ was formed on the catalyst after the temperature rose above $300{ }^{\circ} \mathrm{C}$, so enhancing the activity temperature of Mn-based catalyst to above $300^{\circ} \mathrm{C}$ might be valuable. Existing research proves that molybdenum is a beneficial auxiliary component in $\mathrm{V}_{2} \mathrm{O}_{5} / \mathrm{TiO}_{2}$. Mercury oxidation efficiency of $\mathrm{V}_{2} \mathrm{O}_{5}-\mathrm{MoO}_{3} / \mathrm{TiO}_{2}$ was higher than that of $\mathrm{V}_{2} \mathrm{O}_{5} / \mathrm{TiO}_{2}$. More importantly, the active temperature range was enlarged to $350^{\circ} \mathrm{C}$ [26]. SCR activity of $\mathrm{V}_{2} \mathrm{O}_{5} / \mathrm{MO}_{3} / \mathrm{TiO}_{2}$ was higher than that of $\mathrm{V}_{2} \mathrm{O}_{5} / \mathrm{WO}_{3} / \mathrm{TiO}_{2}$ at $300{ }^{\circ} \mathrm{C}$ [27]. Fewer sulfates were considered to deposit on V/Mo/Ti-S catalyst [28]. Furthermore. More acid sites were also discovered after the addition of Mo into $\mathrm{Ce} / \mathrm{Ti}$ catalyst, which contributed to the enhancement of SCR activity [29]. Therefore, to increase the active temperature of $\mathrm{MnO}_{2} / \mathrm{TiO}_{2}$ for mercury oxidation, the addition of molybdenum to this catalyst may be feasible. Moreover, few studies have focused on the mercury oxidation over Mn-Mo/Ti catalyst, and no research about the role of molybdenum in the catalyst for mercury oxidation has been reported. To develop a more widely applicable Mn-based catalyst, it is worth investigating whether the addition of molybdenum to $\mathrm{MnO}_{2} / \mathrm{TiO}_{2}$ enlarge the active temperature range of this Mn-based catalyst.

To clarify this question, in this study, Mn-Mo/Ti catalyst was prepared and the performance of this catalyst on mercury oxidation in simple $\mathrm{O}_{2} / \mathrm{N}_{2}$ atmosphere at different temperature was investigated. In addition, the mechanism of mercury oxidized by $\mathrm{O}_{2}$ over $\mathrm{Mn}-\mathrm{Mo} / \mathrm{Ti}$ was also examined.

\section{Results and Discussion}

\subsection{Catalyst Characterization}

\subsubsection{Brunauer-Emmett-Teller (BET)}

The pore structure parameters of the three catalysts are listed in Table 1. BJH is the abbreviation of "Barrett Joyner Halenda", meaning the pore size distribution, which refers to the percentage of pore size at all levels in the material calculated by quantity or volume. The Brunauer-Emmett-Teller (BET) surface area of $\mathrm{TM}_{5}$ was $81 \mathrm{~m}^{2} / \mathrm{g}$, and this value decreased to $56 \mathrm{~m}^{2} / \mathrm{g}$ after the addition of $5 \mathrm{wt}$. \% $\mathrm{MoO}_{3}$ into the catalyst. Moreover, the BET surface area of $\mathrm{TMo}_{5}$ was only $26 \mathrm{~m}^{2} / \mathrm{g}$. Figure 1 was the pore diameter distribution of the three catalysts. The pore volume of $\mathrm{TM}_{5} \mathrm{Mo}_{5}\left(0.0507 \mathrm{~cm}^{3} / \mathrm{g}\right) \mathrm{was}$ lower than that of both $\mathrm{TM}_{5}\left(0.0936 \mathrm{~cm}^{3} / \mathrm{g}\right)$ and $\mathrm{TMo}_{5}\left(0.0639 \mathrm{~cm}^{3} / \mathrm{g}\right)$. The addition of molybdenum to $\mathrm{TM}_{5}$ caused both the surface area and pore volume to decrease, which indicated that the interaction might be held between these compositions. 
Table 1. The BET surface area of the three catalysts.

\begin{tabular}{cccc}
\hline Catalysts & BET Surface Area $/ \mathbf{m}^{2} / \mathbf{g}$ & BJH Pore Volume $/ \mathbf{c m}^{3} / \mathbf{g}$ & BJH Average Diameter/nm \\
\hline $\mathrm{TM}_{5}$ & 80.8678 & 0.0936 & 4.5871 \\
$\mathrm{TM}_{5} \mathrm{Mo}_{5}$ & 55.7141 & 0.0507 & 3.8020 \\
$\mathrm{TMo}_{5}$ & 25.9037 & 0.0639 & 9.3176 \\
\hline
\end{tabular}

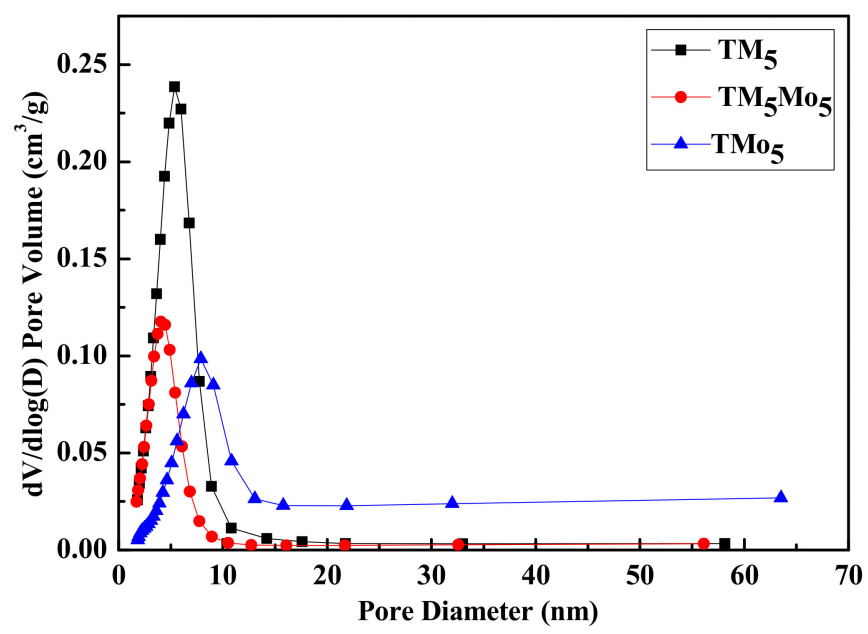

Figure 1. The pore diameter distribution of the catalysts.

\subsubsection{Scanning Electron Microscopy (SEM)}

Figure 2 shows the scanning electron microscopy (SEM) images of $\mathrm{TM}_{5}$ and $\mathrm{TM}_{5} \mathrm{Mo}_{5}$. It is clearly revealed that the addition of molybdenum can significantly change the morphology of the catalyst. Comparing these two catalysts, the surface morphology of $\mathrm{TM}_{5} \mathrm{Mo}_{5}$ was much smoother than that of $\mathrm{TM}_{5}$, and roughly melted materials were exhibited on the surface of $\mathrm{TM}_{5} \mathrm{Mo}_{5}$. This is mainly because molybdenum tends to aggregate during the process of catalyst preparation, where molybdenum was added to calcine titanic acid [30]. Few pores existed at the surface of both catalysts, which was consistent with the results of BET analysis.

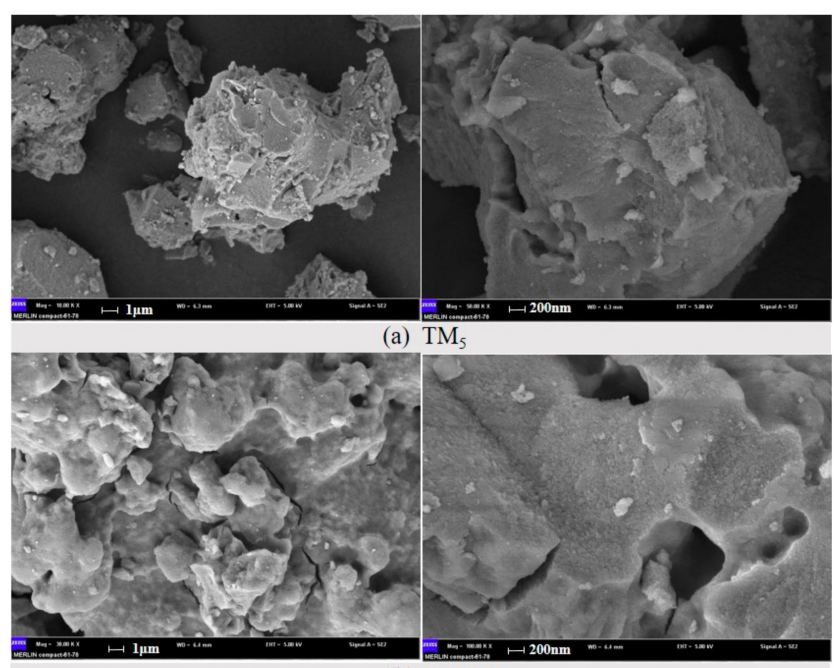

(b) $\mathrm{TM}_{5} \mathrm{Mo}_{5}$

Figure 2. The scanning electron microscopy (SEM) images of (a) $\mathrm{TM}_{5}$ and (b) $\mathrm{TM}_{5} \mathrm{Mo}_{5}$

\subsubsection{X-ray Powder Diffraction (XRD)}

Figure 3 displays the X-ray powder diffraction (XRD) patterns of the three catalysts. Only two types of crystalline were identified in both $\mathrm{TM}_{5} \mathrm{Mo}_{5}$ and $\mathrm{TM}_{5}$, which were the anatase and rutile of 
$\mathrm{TiO}_{2}$. The crystalline at $25.2^{\circ}$ was the typical peak of anatase [26], which was in all three catalysts. No crystal phase of $\mathrm{MoO}_{3}$ and $\mathrm{MnO}_{2}$ was discovered on the surface of $\mathrm{TM}_{5} \mathrm{Mo}_{5}$ and $\mathrm{TM}_{5}$. However, a crystalline at $32^{\circ}$ was found in $\mathrm{TMo}_{5}$, which was the peak of $\mathrm{MoO}_{3}$ according to the result of the joint committee on power diffraction standards (JCPDS). This indicates that the crystal phase of $\mathrm{MoO}_{3}$ tends to change into a non-crystalline state after Mn and Mo are both present in the catalysts. This may be caused by the interaction of $\mathrm{Mn}$ and Mo during the process of catalyst preparation [30]. As for $\mathrm{TM}_{5} \mathrm{Mo}_{5}$ and $\mathrm{TM}_{5}$, both molybdenum and manganese oxides were present in either as small crystallites (less than $4 \mathrm{~nm}$ in diameter) or non-crystalline state [27].

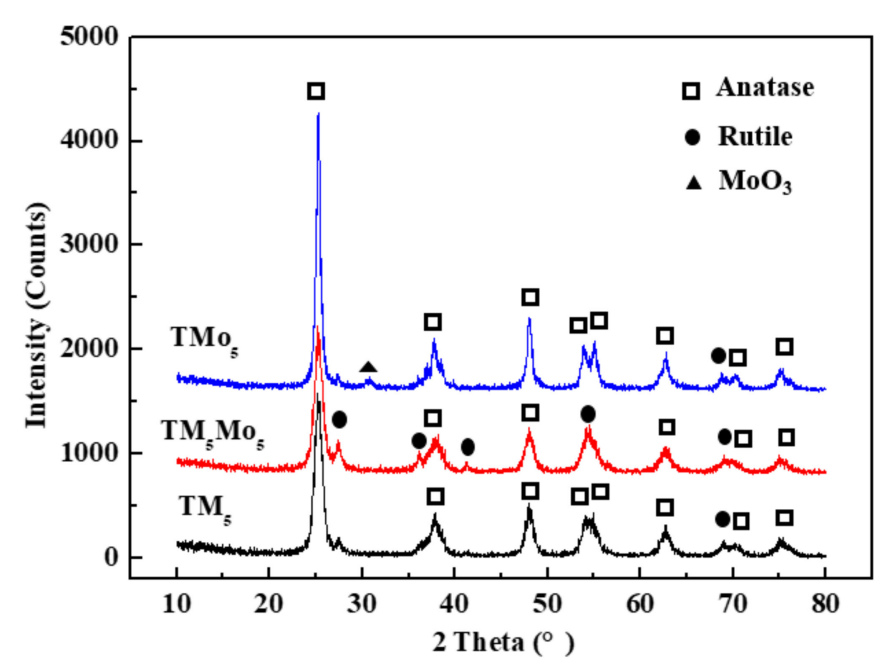

Figure 3. The X-ray powder diffraction (XRD) results of the three catalyst.

\subsubsection{X-ray Photoelectron Spectroscopy (XPS)}

Mn $2 p$ results of $\mathrm{TM}_{5}$ and $\mathrm{TM}_{5} \mathrm{Mo}_{5}$ are shown in Figure 4. Two peaks of Mn $2 \mathrm{p} 3 / 2$ are exhibited at $636-647 \mathrm{eV}$, which are respectively $\mathrm{Mn}^{2+}$ at $641 \mathrm{eV}$ and $\mathrm{Mn}^{4+}$ at $642.4 \mathrm{eV}$ on the surface of $\mathrm{TM}_{5}$ in Figure $4 \mathrm{a}[8,31]$. Two peaks of $\mathrm{Mn} 2 \mathrm{p} 3 / 2$ are also noted at $636-647 \mathrm{eV}$ on the surface of $\mathrm{TM}_{5} \mathrm{Mo}_{5}$ after the addition of $\mathrm{MoO}_{3}$, which are $\mathrm{Mn}^{3+}$ at $641.7 \mathrm{eV}$ and $\mathrm{Mn}^{4+}$ at $642.8 \mathrm{eV}$ [8]. Comparing the results in Figure $4 \mathrm{a}, \mathrm{b}$, higher valence manganese was discovered on the surface of $\mathrm{TM}_{5} \mathrm{Mo}_{5}$. It should be noted that the addition of molybdenum enhanced the binding energy of manganese oxide transformed to high electron bit. Research into typical SCR catalysts (V-Mo/Ti) clarified that the presence of both molybdenum and vanadium in the catalyst cause the formation of stronger acid sites because of the interaction of Mo and V on surface of the catalysts [27], and molybdenum oxide could assist in oxidization of vanadium in low valence to higher valence [26]. As for $\mathrm{TM}_{5} \mathrm{Mo}_{5}$, the same effect of molybdenum might cause the change of electron bit of manganese in $\mathrm{TM}_{5}$ and $\mathrm{TM}_{5} \mathrm{Mo}_{5}$, since the interaction of $\mathrm{Mn}$ and Mo during the process of catalysts preparation may occur depending on the results of XRD analysis. 


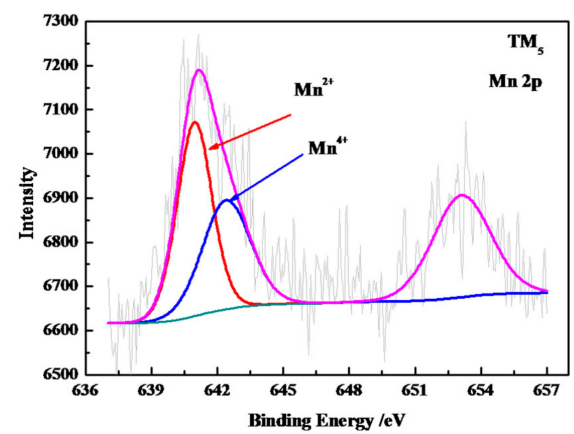

(a)

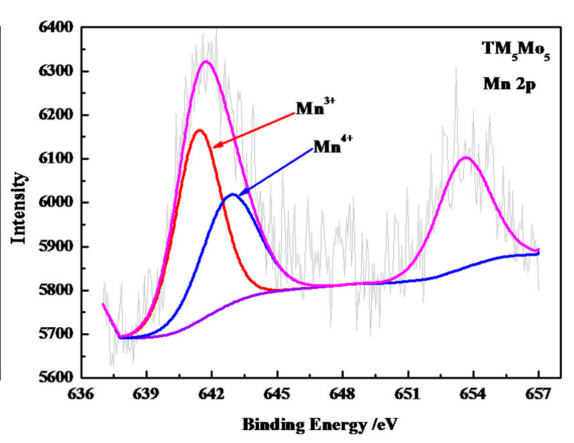

(b)

Figure 4. The XPS analysis of Mn 2p for (a) $\mathrm{TM}_{5}$; and (b) $\mathrm{TM}_{5} \mathrm{Mo}_{5}$.

Figure 5 shows the $\mathrm{O} 1 \mathrm{~s}$ results of the three catalysts. Four peaks of $\mathrm{O} 1 \mathrm{~s}$ are discovered at $526-534 \mathrm{eV}$ on the surface of $\mathrm{TM}_{5}$, which are $\mathrm{TiO}_{2}$ at $529 \mathrm{eV}$ and $530.1 \mathrm{eV}, \mathrm{Ti}_{2} \mathrm{O}_{3}$ at $531.1 \mathrm{eV}, \mathrm{MnO}_{\mathrm{x}}$ at $529.5 \mathrm{eV}$, respectively. In Figure 5b, three peaks, which are $\mathrm{TiO}_{2}$ at $529.7 \mathrm{eV}, \mathrm{MoO}_{3}$ at $530.4 \mathrm{eV}$ and $\mathrm{Ti}_{2} \mathrm{O}_{3}$ at $531.1 \mathrm{eV}$, were consulted on the surface of $\mathrm{TMo}_{5}$. Four peaks, which are $\mathrm{TiO}_{2}$ at $530 \mathrm{eV}$ and $529.3 \mathrm{eV}$, $\mathrm{MoO}_{3}$ at $530.48 \mathrm{eV}$ and $\mathrm{TiO}_{0.73}$ at $531.5 \mathrm{eV}$, are found on the surface of $\mathrm{TM}_{5} \mathrm{Mo}_{5}$. The addition of $\mathrm{MnO}_{2}$ significantly weakened the intensity of $\mathrm{TiO}_{2}$, which means that the surface of $\mathrm{TM}_{5} \mathrm{Mo}_{5}$ became complex for the interaction between manganese and molybdenum. In Figure $5 \mathrm{c}$, the $\mathrm{Mn}-\mathrm{O}$ component disappeared, but this does not mean that there were no $\mathrm{Mn}-\mathrm{O}$ components on the surface of $\mathrm{TM}_{5} \mathrm{Mo}_{5}$. During the X-ray photoelectron spectroscopy (XPS) analysis of $\mathrm{O} 1 \mathrm{~s}$, the binding energy of peaks for $\mathrm{TiO}_{2}$ and $\mathrm{MnO}_{\mathrm{x}}$ was partly overlapped, e.g., the peak of $529.3 \mathrm{eV}$ was $\mathrm{TiO}_{2}$ and the peak at $529.5 \mathrm{eV}$ was $\mathrm{MnO}_{\mathrm{x}}$, and $\mathrm{TiO}_{2}$ accounts for most of the catalyst. $\mathrm{Mn}-\mathrm{O}$ components on the surface of $\mathrm{TM}_{5} \mathrm{Mo}_{5}$ were hidden, especially after the addition of Mo, because of the binding energy of peaks for $\mathrm{TiO}_{2}$ was transferred to near $529.5 \mathrm{eV}$. Therefore, XPS analysis of Mn 2p in Figure 6 was the main basis for the following results.

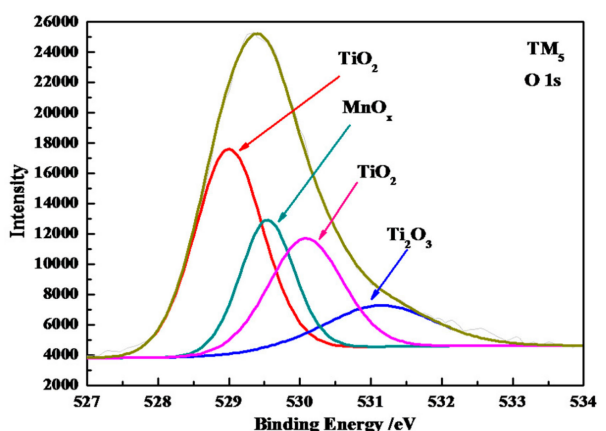

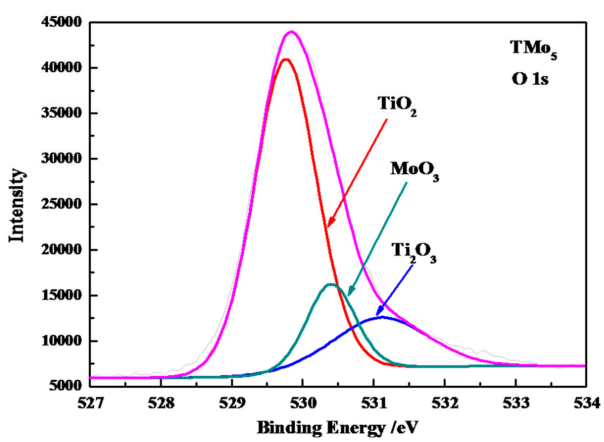

(b) (a)

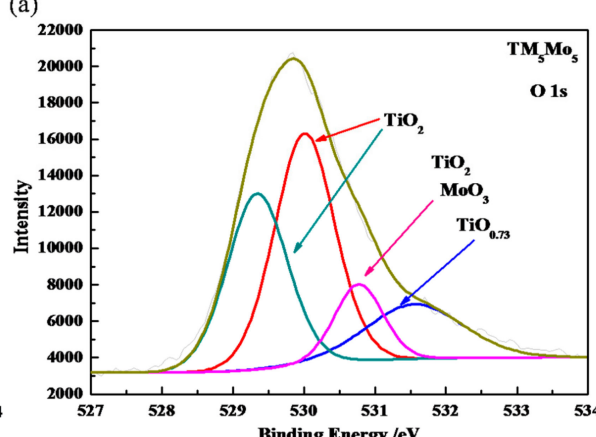

(c)

Figure 5. The XPS analysis of $\mathrm{O} 1 \mathrm{~s}$ for $(\mathbf{a}) \mathrm{TM}_{5} ;(\mathbf{b}) \mathrm{TMo}_{5}$ and (c) $\mathrm{TM}_{5} \mathrm{Mo}_{5}$. 


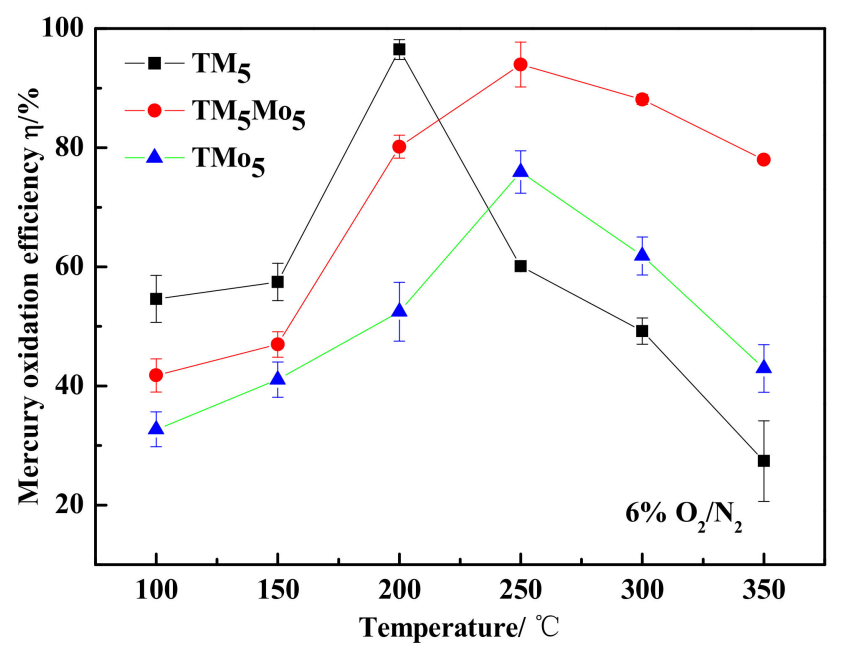

Figure 6. The effect of temperature on mercury oxidation over $\mathrm{TM}_{5} \mathrm{Mo}_{5}$.

\subsection{Effect of Temperature}

Figure 6 exhibits the effect of temperature on mercury oxidation over these catalysts in $6 \% \mathrm{O}_{2} / \mathrm{N}_{2}$. The mercury oxidation efficiency of $\mathrm{TM}_{5}$ increased as the temperature rose from $100{ }^{\circ} \mathrm{C}$ to $200{ }^{\circ} \mathrm{C}$. However, this value of $\mathrm{TM}_{5}$ decreased immediately when the temperature was above $200{ }^{\circ} \mathrm{C}$. The optimal temperature range of $\mathrm{TM}_{5}$ for mercury oxidation was only at the point of $200{ }^{\circ} \mathrm{C}$, with mercury oxidation efficiency over $95 \%$. Mercury oxidation efficiency of $\mathrm{TM}_{5}$ decreased to $60 \%$ at $250{ }^{\circ} \mathrm{C}, 49 \%$ at $300{ }^{\circ} \mathrm{C}$, and $27 \%$ at $350{ }^{\circ} \mathrm{C}$, respectively. As for $\mathrm{TM}_{5} \mathrm{Mo}_{5}$, the mercury oxidation efficiency rose as the temperature increased. Mercury oxidation efficiency of $\mathrm{TM}_{5} \mathrm{Mo}_{5}$ was over $80 \%$ when the temperature was above $200{ }^{\circ} \mathrm{C}$, and the optimal mercury oxidation efficiency was $93 \%$ at $250{ }^{\circ} \mathrm{C}$. Moreover, this value was $88 \%$ at $300{ }^{\circ} \mathrm{C}$ and $77 \%$ at $350{ }^{\circ} \mathrm{C}$, respectively. As for $\mathrm{TMo}_{5}$, the best mercury oxidation efficiency was only $76 \%$ at $250{ }^{\circ} \mathrm{C}$. Ji et al. [20] reported that the optimal mercury oxidation efficiency of $\mathrm{MnO}_{2} / \mathrm{TiO}_{2}$ was $90 \%$, and $\mathrm{Wu}$ et al. [21] also proved that the best mercury oxidation efficiency of Mn-based catalyst was over $90 \%$. Reporting on the above research, the Mn-based catalyst in this work also had similar mercury oxidation ability.

The results in Figure 6 indicate that the addition of molybdenum to $\mathrm{TM}_{5}$ not only enhances the mercury oxidation ability, but also expands the optimal temperature range of mercury oxidation over $\mathrm{TM}_{5} \mathrm{Mo}_{5}$. Marshneva et al. [13] points out that molybdenum could improve the activity of the SCR catalyst in the De- $\mathrm{NO}_{x}$ process. The sulfur resistance of molybdenum was discovered in the $\mathrm{Mn} / \alpha-\mathrm{Al}_{2} \mathrm{O}_{3}$ catalyst for mercury oxidation [32]. The primary result was that the addition of molybdenum could optimize the structure of the catalyst and promote the main active site transformation to a more active state. Additionally, other curious phenomena were also displayed in Figure 6. When the temperature was below $200{ }^{\circ} \mathrm{C}$, the mercury oxidation ability of the three catalysts followed in the order $\mathrm{TM}_{5}>$ $\mathrm{TM}_{5} \mathrm{Mo}_{5}>\mathrm{TMo}_{5}$. However, the order was changed to $\mathrm{TM}_{5} \mathrm{Mo}_{5}>\mathrm{TMo}_{5}>\mathrm{TM}_{5}$, when the temperature was over $250{ }^{\circ} \mathrm{C}$. Existing research states that mercury oxidation over catalyst follows two primary steps: $\mathrm{Hg}^{0}$ should be first adsorbed on the catalyst surface, and then the adsorbed mercury is oxidized by the oxidizing components on the catalyst surface. The BET surface area of the three catalysts follows the order $\mathrm{TM}_{5}>\mathrm{TM}_{5} \mathrm{Mo}_{5}>\mathrm{TMo}_{5}$, and this was consistent with the mercury oxidation ability of the three catalysts at temperatures below $200^{\circ} \mathrm{C}$. This implies that the first step determines the mercury oxidation efficiency of the catalysts when the temperature is below $200^{\circ} \mathrm{C}$. During this temperature range, $\mathrm{Hg}^{0}$ is more easily physically adsorbed on the surface of $\mathrm{TM}_{5}$ due to having the highest surface area of the three catalysts. When the temperature is above $250{ }^{\circ} \mathrm{C}$, the advantage of the BET surface area is weakened. Instead, oxidizing components on the catalyst surface play a primary role in the process of mercury oxidation over these catalysts. The XPS analysis results suggest that a much higher quantity of manganese is in the high-valance state on the surface of $\mathrm{TM}_{5} \mathrm{Mo}_{5}$, which is the core component for 
mercury oxidation. Therefore, mercury oxidation efficiency of $\mathrm{TM}_{5} \mathrm{Mo}_{5}$ is higher than that of other two catalysts at temperatures above $250^{\circ} \mathrm{C}$.

\subsection{Effect of $\mathrm{O}_{2}$}

Figure 7 shows the mercury oxidation efficiency of $\mathrm{TM}_{5} \mathrm{Mo}_{5}$ in two conditions, with or without $6 \% \mathrm{O}_{2}$ at $250{ }^{\circ} \mathrm{C}$. It shows that the mercury oxidation efficiency of $\mathrm{TM}_{5} \mathrm{Mo}_{5}$ in $6 \% \mathrm{O}_{2} / \mathrm{N}_{2}$ is $93 \%$ and the value is only $45 \%$ in pure $\mathrm{N}_{2}$ after $2 \mathrm{~h}$. It suggests that $\mathrm{O}_{2}$ plays an important role in the process of $\mathrm{Hg}^{0}$ oxidation over $\mathrm{TM}_{5} \mathrm{Mo}_{5}$. It has been shown that $\mathrm{Hg}^{0}$ oxidized by $\mathrm{O}_{2}$ over catalyst mainly follows the Mars-Maessen mechanism [5,8,26]. Equations (1)-(4) describe the reaction process. Besides the primary two steps mentioned in Section 3.2, the third step highlights the effect of oxygen in the circle of the catalytic reaction. As for $\mathrm{TM}_{5} \mathrm{Mo}_{5}$, elemental mercury is first adsorbed on the catalyst surface; subsequently, the adsorbed elemental mercury is oxidized by manganese in high valance, such as $\mathrm{MnO}_{2}$ and $\mathrm{Mn}_{2} \mathrm{O}_{3}$. The manganese in high valance itself is reduced to the lower valance, which mainly is $\mathrm{MnO}$. In pure $\mathrm{N}_{2}$ condition, no oxidizing substance is supplied in the atmosphere; after $\mathrm{MnO}_{2}$ or $\mathrm{Mn}_{2} \mathrm{O}_{3}$ is reduced to $\mathrm{MnO}$, the reduced manganese cannot be re-oxidized to a high-valance state. Therefore, mercury oxidation efficiency of $\mathrm{TM}_{5} \mathrm{Mo}_{5}$ decreases and the value is lower than $45 \%$ after $2 \mathrm{~h}$. In $6 \% \mathrm{O}_{2} / \mathrm{N}_{2}$, as the oxidability of $\mathrm{O}_{2}, \mathrm{MnO}$ could be re-oxidized to $\mathrm{MnO}_{2}$ or $\mathrm{Mn}_{2} \mathrm{O}_{3}$. Accordingly, more elemental mercury could be oxidized by the oxidizing substance on the surface of $\mathrm{TM}_{5} \mathrm{Mo}_{5}$ and the value was even higher than $93 \%$ after $2 \mathrm{~h}$ tests.

$$
\begin{gathered}
\mathrm{A}(\mathrm{g}) \leftrightarrow \mathrm{A}(\text { ads }) \\
\mathrm{A}(\text { ads })+\mathrm{M}_{\mathrm{x}} \mathrm{O}_{\mathrm{y}} \rightarrow \mathrm{AO}(\text { ads })+\mathrm{M}_{\mathrm{x}} \mathrm{O}_{\mathrm{y}-1} \\
\mathrm{M}_{\mathrm{x}} \mathrm{O}_{\mathrm{y}-1+1 / 2 \mathrm{O}_{2}} \rightarrow \mathrm{M}_{\mathrm{x}} \mathrm{O}_{\mathrm{y}} \\
\mathrm{AO}(\text { ads }) \rightarrow \mathrm{AO}(\mathrm{g})
\end{gathered}
$$

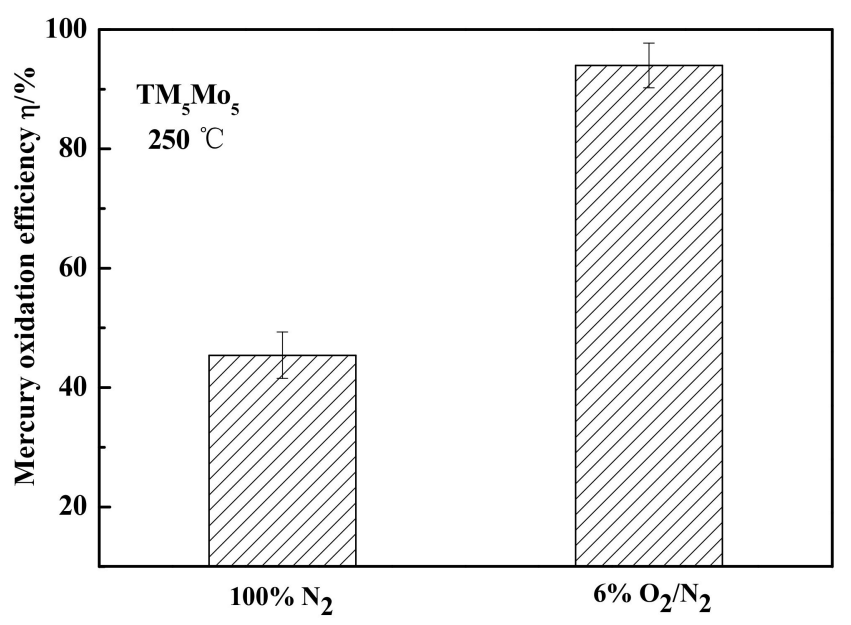

Figure 7. The effect of oxygen on mercury oxidation over $\mathrm{TM}_{5} \mathrm{Mo}_{5}$.

\subsection{Stability Test}

To clarify the mechanism of mercury oxidation over $\mathrm{TM}_{5} \mathrm{Mo}_{5}$, a type of $20 \mathrm{~h}$ tests in $6 \% \mathrm{O}_{2} / \mathrm{N}_{2}$ atmosphere at $200{ }^{\circ} \mathrm{C}$ and $300{ }^{\circ} \mathrm{C}$ was designed. It represents the low-temperature mercury oxidation ability of $\mathrm{TM}_{5} \mathrm{Mo}_{5}$ at $200{ }^{\circ} \mathrm{C}$, while it represents the high-temperature mercury oxidation ability of $\mathrm{TM}_{5} \mathrm{Mo}_{5}$ at $300{ }^{\circ} \mathrm{C}$. Figure 8 shows that mercury oxidation efficiency of $\mathrm{TM}_{5} \mathrm{Mo}_{5}$ was in the range of $88 \%$ to $93 \%$ at $300{ }^{\circ} \mathrm{C}$, while the value was $78 \%$ to $83 \%$ at $200{ }^{\circ} \mathrm{C}$ during the $20 \mathrm{~h}$ tests. This indicates that the mercury oxidation ability of $\mathrm{TM}_{5} \mathrm{Mo}_{5}$ is much stronger at $300{ }^{\circ} \mathrm{C}$ than at $200{ }^{\circ} \mathrm{C}$. In addition, mercury oxidation efficiency of $\mathrm{TM}_{5} \mathrm{Mo}_{5}$ is steady at both temperatures. To explain this phenomenon, 
XPS was introduced to characterize the tested samples. Figure 9 shows the Mn $2 p$ results of the two tested samples. $\mathrm{MnO}, \mathrm{Mn}_{2} \mathrm{O}_{3}$, and $\mathrm{MnO}_{2}$ were discovered on the surface of both samples. The result of Figure $4 \mathrm{~b}$ shows that no $\mathrm{MnO}$ exists on the surface of initial $\mathrm{TM}_{5} \mathrm{Mo}_{5}$. This illustrates that elemental mercury is mainly oxidized by $\mathrm{Mn}_{2} \mathrm{O}_{3}$ and $\mathrm{MnO}_{2}$ on the surface of $\mathrm{TM}_{5} \mathrm{Mo}_{5}$, and partial $\mathrm{MnO}$ is formed on the catalyst surface ${ }^{41}$. Additionally, peak area ratio of $\mathrm{Mn}_{2} \mathrm{O}_{3}$ and $\mathrm{MnO}_{2}$ in Figure 9a was 0.31 , and the ratio increased to 0.79 in Figure $9 \mathrm{~b}$. This was in accordance with the results of the mercury oxidation ability at these two temperatures. When the catalytic reaction was steady, more $\mathrm{Mn}^{4+}$ on the surface participated in the reaction at $300^{\circ} \mathrm{C}$ than that at $200{ }^{\circ} \mathrm{C}$. Therefore, the quantity of $\mathrm{MnO}_{2}$ at $300{ }^{\circ} \mathrm{C}$ was less than that at $200^{\circ} \mathrm{C}$ and the mercury oxidation ability was to the contrary. This proves that the main active component for mercury oxidation is manganese in high valance and the addition of molybdenum enhanced the mercury oxidation ability of $\mathrm{MnO}_{2}-\mathrm{MoO}_{3} / \mathrm{TiO}_{2}$.

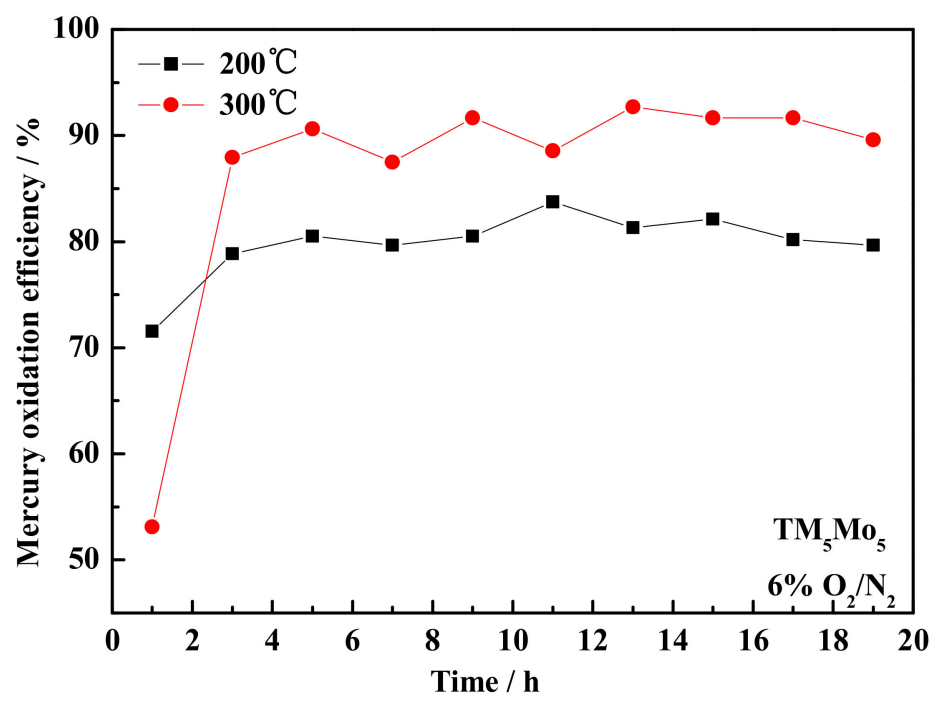

Figure 8. Long time test of the mercury oxidation over $\mathrm{TM}_{5} \mathrm{Mo}_{5}$ at 200 and $300{ }^{\circ} \mathrm{C}$.

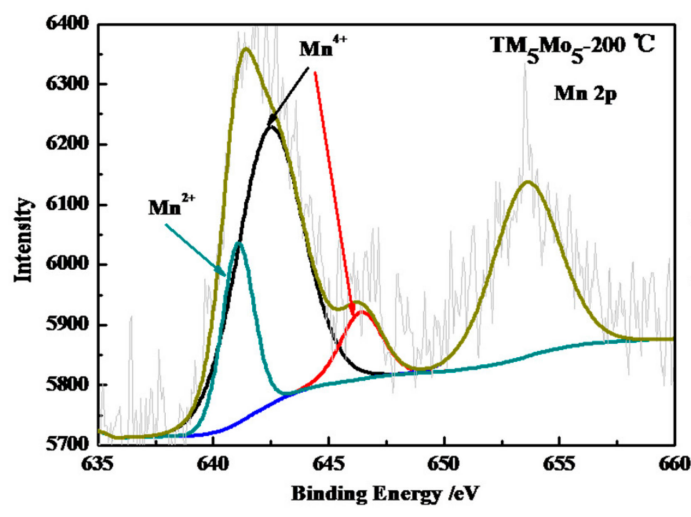

(a)

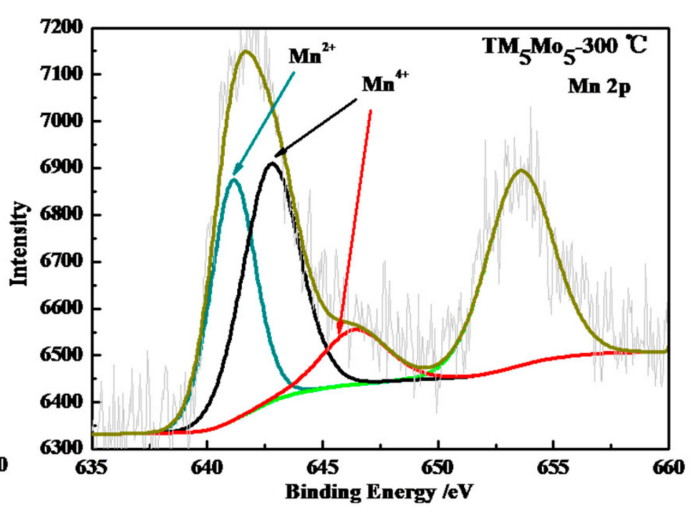

(b)

Figure 9. XPS results of long-term test samples: (a) $20 \mathrm{~h}$ test at $200^{\circ} \mathrm{C}$; (b) $20 \mathrm{~h}$ test at $300^{\circ}$.

\section{Experimental}

\subsection{Catalyst Preparation}

The catalysts were prepared by sol-gel method, and a detailed synthesis process is shown in Figure 10. Main raw materials were tetrabutyl titanate, ethanol, ammonia, nitric acid, molybdenum trioxide, and $\mathrm{Mn}\left(\mathrm{NO}_{3}\right)_{2}$ solution. All the chemical reagents were analytically pure. The tetrabutyl titanate was first dissolved in isometric volume ethanol solution to develop the sol. Then ammonia, nitric acid, manganese nitrate, and molybdenum were successively included in the solution. After 
blending, drying, calcining, and grinding, the catalysts were pulverized to $45-100 \mu \mathrm{m}$. Three kinds of catalysts, named $\mathrm{TM}_{5}\left(5\right.$ wt. $\left.\% \mathrm{MnO}_{2}\right), \mathrm{TM}_{5} \mathrm{Mo}_{5}\left(5\right.$ wt. $\% \mathrm{MnO}_{2}$ and $\mathrm{MoO}_{3}$ ) and $\mathrm{TMo}_{5}\left(5\right.$ wt. $\% \mathrm{MoO}_{3}$ ) were prepared in this study.

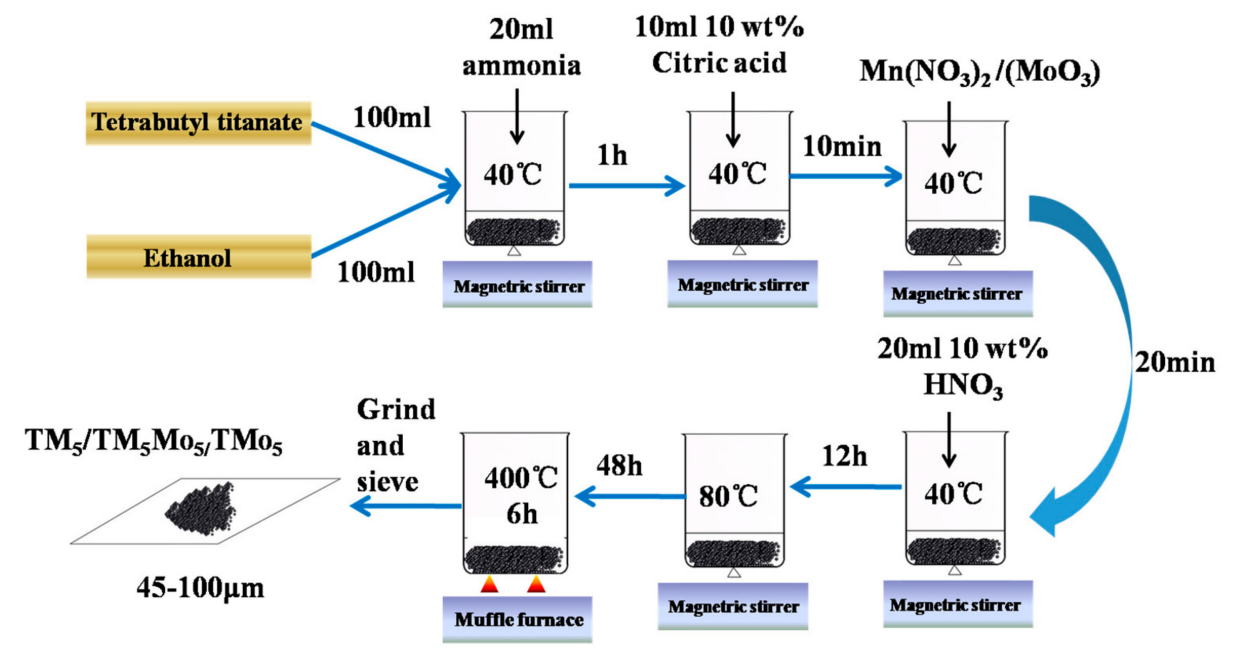

Figure 10. The progress of catalysts preparation.

\subsection{Characterization Equipment}

The Brunauer-Emmett-Teller (BET) surface area and pore size distribution were controlled by ASAP 2020 (Micromeritics, America) [33-35]. X-ray photoelectron spectroscopy (XPS) and XRD of the three catalysts were determined by VG Multilab 2000 X-ray Photoelectron Spectroscopy and X'pert PRO X-ray powder diffraction (PANalytical, Holland) [36-38], respectively. Sirion 200 scanning electron microscope (FEI, Holland) was used to characterize the SEM of the three catalysts [39].

\subsection{Experimental Conditions}

Mercury oxidation ability of the three catalysts was tested on a laboratory scale fixed-bed experimental system. As showed in Figure 11, the experimental system was made up of three parts: a fixed-bed reactor, a mercury permeation source, and a mercury detection device. Detailed information of the fixed-bed reactor and mercury permeation source has been described in other research [26]. The fixed-bed reactor was a vertical furnace, and a quartz tube (ID: $16 \mathrm{~mm}$ ) with a length $550 \mathrm{~mm}$ was equipped in the furnace. A sieve plate used to load the catalyst was in the middle of the quartz tube. The mercury permeation source was a U-shaped quartz tube, which was placed in a thermostat-controlled water bath. The mercury permeation tube was positioned in the U-shaped quartz tube, and mercury was transported out by $\mathrm{N}_{2}$. The elemental mercury concentration was determined by QM201G (measuring ranges: 0-100 $\mu \mathrm{g} / \mathrm{L}$, Sensitivity: $0.1 \mu \mathrm{g} / \mathrm{L}$, Qing'an Inc. Changzhou, China). Before each test, the mercury content standard curve of QM201G was determined. The initial $\mathrm{Hg}^{0}$ concentration in the experimental flue gas was $55 \pm 2 \mu \mathrm{g} / \mathrm{m}^{3}$. The total flow rate of each experiment was $1 \mathrm{~L} / \mathrm{min}$, and elemental mercury was transported by $0.5 \mathrm{~L} / \mathrm{min} \mathrm{N}_{2}$. The weight of the catalyst in each run was $0.15 \mathrm{~g}$, and the gas reciprocal space velocity was over $180,000 \mathrm{~h}^{-1}$, which was calculated by dividing the volume of the catalyst by the volume of gas passing through the reactor in one hour. The experimental conditions are listed in Table 2. 


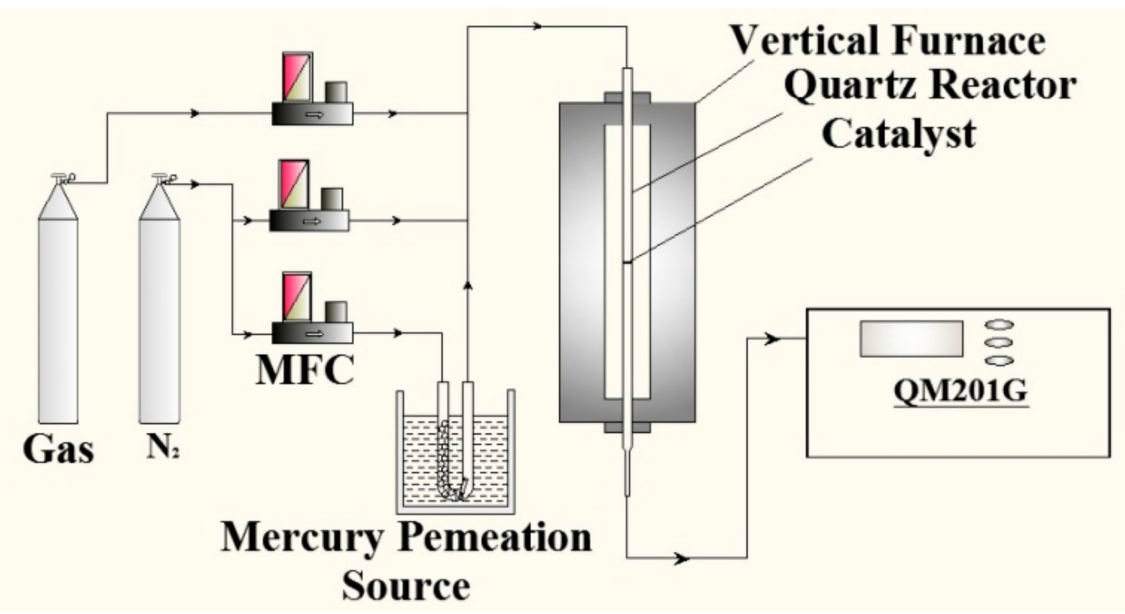

Figure 11. The experimental system.

Table 2. The experimental conditions.

\begin{tabular}{ccc}
\hline Experiments & Catalysts & Experimental Conditions \\
\hline Impact of temperature & $\mathrm{TM}_{5} \mathrm{Mo}_{5} / \mathrm{TM}_{5} / \mathrm{TMo}_{5}$ & $100{ }^{\circ} \mathrm{C} / 150{ }^{\circ} \mathrm{C} / 200{ }^{\circ} \mathrm{C} / 250^{\circ} \mathrm{C} / 00{ }^{\circ} \mathrm{C} / 350{ }^{\circ} \mathrm{C}$ \\
Impact of oxygen & $\mathrm{TM}_{5} \mathrm{Mo}_{5}$ & $100 \% \mathrm{~N}_{2} / 6 \% \mathrm{O}_{2} / \mathrm{N}_{2}, 250{ }^{\circ} \mathrm{C}$ \\
\hline
\end{tabular}

Mercury oxidation efficiency was used to describe $\mathrm{Hg}^{0}$ oxidized ability of the catalysts. This was determined by Equation (5), and a detailed introduction of this equation has been made in other research $[10,17,26,40]$. When the mercury content at the outlet of the reactor was varied below the range of $5 \%$ in $1 \mathrm{~h}$, it could be assumed that the experiment reached a stable state. To ensure the accuracy of the results, every experiment was replicated three times.

$$
\eta=\frac{\Delta \mathrm{Hg}^{0}}{\mathrm{Hg}^{0}{ }_{\text {in }}}=\frac{\Delta \mathrm{Hg}^{0}-\mathrm{Hg}^{0}{ }_{\text {out }}}{\mathrm{Hg}^{0}{ }_{\text {in }}} \times 100 \%
$$

$\eta$ : The mercury oxidation efficiency of the catalyst

$\mathrm{Hg}^{0}$ in: The elemental mercury concentration at the inlet of the reactor

$\mathrm{Hg}^{0}$ out: The elemental mercury concentration at the outlet of the reactor

\section{Conclusions}

This work focused on the unique performance of mercury oxidation over $\mathrm{MnO}_{2}-\left(\mathrm{MoO}_{3}\right) / \mathrm{TiO}_{2}$. XPS was put in place to clarify the mechanism of mercury oxidation over this catalyst. Molybdenum enhanced manganese transference from a low-valance state to a high-valance state, which increased the active sites on the surface of the catalyst for mercury oxidation. Molybdenum effectively widened the optimal temperature range of the catalyst for mercury oxidation. The optimal temperature of $\mathrm{TM}_{5}$ for mercury oxidation was only a point at $200{ }^{\circ} \mathrm{C}$, while the best temperature range of $\mathrm{TM}_{5} \mathrm{Mo}_{5}$ for mercury oxidation was 200 to $350^{\circ} \mathrm{C}$. $\mathrm{O}_{2}$ plays an important role for mercury oxidation over $\mathrm{TM}_{5} \mathrm{Mo}_{5}$, and this process follows the Mars-Maessen mechanism. Long-term tests indicated that the oxygen component of the catalyst surface was more active at $200{ }^{\circ} \mathrm{C}$ than that at $300{ }^{\circ} \mathrm{C}$.

Author Contributions: Writing-review \& editing, B.Z.; Data curation, X.Z.; Writing-original draft, Y.L.; Methodology, Y.W.; Resources, L.Q. \& W.C. All authors have read and agreed to the published version of the manuscript.

Funding: This research was funded by National Natural Science Foundation of China, grant number 51906182; The Open Project Foundation of Hubei Key Laboratory for Efficient Use and Agglomeration of Metallurgic Mineral 
Resources grant number 2019zy003; The Open Project Foundation of Hubei Key Laboratory for Efficient Use and Agglomeration of Metallurgic Mineral Resources grant number 2019zy007.

Conflicts of Interest: The authors declare no conflicts of interest.

\section{References}

1. Huggins, F.E.; Senior, C.L.; Chu, P.; Ladwig, K.; Huffman, G.P. Selenium and arsenic speciation in fly ash from full-scale coal-burning utility plants. Environ. Sci. Technol. 2007, 41, 3284-3289. [CrossRef] [PubMed]

2. Han, J.; Xiong, Z.; Zhao, B.; Liang, Y.; Wang, Y.; Qin, L. A prediction of arsenic and selenium emission during the process of bituminous and lignite coal co-combustion. Chem. Pap. 2020. [CrossRef]

3. Yang, J.; Zhao, Y.; Liang, S.; Zhang, S.; Ma, S.; Li, H.; Zhang, J.; Zheng, C. Magnetic iron-manganese binary oxide supported on carbon nanofiber $\left(\mathrm{Fe}_{3-\mathrm{x}} \mathrm{Mn}_{\mathrm{x}} \mathrm{O}_{4} / \mathrm{CNF}\right)$ for efficient removal of $\mathrm{Hg} 0$ from coal combustion flue gas. Chem. Eng. J. 2018, 334, 216-224. [CrossRef]

4. Galbreath, K.C.; Zygarlicke, C.J. Mercury speciation in coal combustion and gasification flue gases. Environ. Sci. Technol. 1996, 30, 2421-2426. [CrossRef]

5. Presto, A.A.; Granite, E.J. Survey of catalysts for oxidation of mercury in flue gas. Environ. Sci. Technol. 2006, 40, 5601-5609. [CrossRef]

6. Cao, T.; Li, Z.; Xiong, Y.; Yang, Y.; Xu, S.; Bisson, T.; Gupta, R.; Xu, Z. Silica-silver nanocomposites as regenerable sorbents for hg0 removal from flue gases. Environ. Sci. Technol. 2017, 51, 11909-11917. [CrossRef]

7. Lopez-Anton, M.A.; Gil, R.R.; Fuente, E.; Díaz-Somoano, M.; Martínez-Tarazona, M.R.; Ruiz, B. Activated carbons from biocollagenic wastes of the leather industry for mercury capture in oxy-combustion. Fuel 2015, 142 (Suppl. C), 227-234. [CrossRef]

8. Zhou, Z.; Liu, X.; Hu, Y.; Xu, J.; Cao, X.E.; Liao, Z.; Xu, M. Investigation on synergistic oxidation behavior of $\mathrm{NO}$ and $\mathrm{Hg}^{0}$ during the newly designed fast SCR process. Fuel 2018, 225, 134-139. [CrossRef]

9. Cheng, J.; Wang, X.; Li, Y.; Ning, P. Adsorption and catalytic oxidation of mercury over $\mathrm{MnO}_{\mathrm{x}} / \mathrm{TiO}_{2}$ under low-temperature conditions. Ind. Eng. Chem. Res. 2017, 56, 14419-14429. [CrossRef]

10. Wang, P.; Su, S.; Xiang, J.; You, H.; Cao, F.; Sun, L.; Hu, S.; Zhang, Y. Catalytic oxidation of Hg0 by $\mathrm{MnO}_{\mathrm{x}}-\mathrm{CeO}_{2} / \gamma-\mathrm{Al}_{2} \mathrm{O}_{3}$ catalyst at low temperatures. Chemosphere 2014, 101 (Suppl. C), 49-54. [CrossRef]

11. Eswaran, S.; Stenger, H.G. Understanding mercury conversion in selective catalytic reduction (SCR) catalysts. Energy Fuels 2005, 19, 2328-2334. [CrossRef]

12. Machalek, T.; Ramavajjala, M.; Richardson, M.; Richardson, C.; Dene, C.; Goeckner, B.; Anderson, H.; Morris, E. Pilot Evaluation of Flue Gas Mercury Reactions Across an SCR Unit. In Proceedings of the Environmental Protection Agencys Air and Waste Management Association Combined Power Plant Air Pollution Control Symposium, Washington, DC, USA, 19-22 May 2003. Paper No. 64.

13. Marshneva, V.I.; Slavinskaya, E.M.; Kalinkina, O.V.; Odegova, G.V.; Moroz, E.M.; Lavrova, G.V.; Salanov, A.N. The influence of support on the activity of monolayer vanadia-titania catalysts for selective catalytic reduction of NO with ammonia. J. Catal. 1995, 155, 171-183. [CrossRef]

14. Zhao, B.; Han, J.; Qin, L.; Chen, W.; Zhou, Z.; Xing, F. Impact of individual flue gas components on mercury oxidation over a $\mathrm{V}_{2} \mathrm{O}_{5}-\mathrm{MoO}_{3} / \mathrm{TiO}_{2}$ catalyst. New J. Chem. 2018, 42, 20190-20196. [CrossRef]

15. Xiong, S.; Xiao, X.; Huang, N.; Dang, H.; Liao, Y.; Zou, S.; Yang, S. Elemental mercury oxidation over Fe-Ti-Mn spinel: Performance, mechanism, and reaction kinetics. Environ. Sci. Technol. 2017, 51, 531-539. [CrossRef]

16. Li, H.; Wang, S.; Wang, X.; Tang, N.; Pan, S.; Hu, J. Comparative study of $\mathrm{Co} / \mathrm{TiO}_{2}, \mathrm{Co}-\mathrm{Mn} / \mathrm{TiO} 2$ and Co-Mn/Ti-Ce catalysts for oxidation of elemental mercury in flue gas. Chem. Pap. 2017, 71, 1569-1578. [CrossRef]

17. Li, H.; Wu, C.-Y.; Li, Y.; Zhang, J. Superior activity of $\mathrm{MnO}_{\mathrm{x}}-\mathrm{CeO}_{2} / \mathrm{TiO}_{2}$ catalyst for catalytic oxidation of elemental mercury at low flue gas temperatures. Appl. Catal. B Environ. 2012, 111-112, 381-388. [CrossRef]

18. Zhou, Z.J.; Liu, X.; Hu, Y.; Liao, Z.; Cheng, S.; Xu, M. An efficient sorbent based on $\mathrm{CuCl}_{2}$ loaded $\mathrm{CeO}_{2}-\mathrm{ZrO}_{2}$ for elemental mercury removal from chlorine-free flue gas. Fuel 2018, 216, 356-363. [CrossRef]

19. Peña, D.A.; Uphade, B.S.; Smirniotis, P.G. $\mathrm{TiO}_{2}$-supported metal oxide catalysts for low-temperature selective catalytic reduction of $\mathrm{NO}$ with $\mathrm{NH}_{3}$ : I. Evaluation and characterization of first row transition metals. J. Catal. 2004, 221, 421-431. [CrossRef] 
20. Ji, L.; Sreekanth, P.M.; Smirniotis, P.G.; Thiel, S.W.; Pinto, N.G. manganese oxide/titania materials for removal of NOx and elemental mercury from flue gas. Energy Fuels 2008, 22, 2299-2306. [CrossRef]

21. Wu, Y.; Xu, W.; Yang, Y.; Wang, J.; Zhu, T. Support effect of Mn-based catalysts for gaseous elemental mercury oxidation and adsorption. Catal. Sci. Technol. 2018, 8, 297-306. [CrossRef]

22. Wu, Y.; Xu, W.; Yang, Y.; Shao, M.; Zhu, T.; Tong, L. Removal of gas-phase $\mathrm{Hg}^{0}$ by Mn/montmorillonite K10. RSC Adv. 2016, 6, 104294-104302. [CrossRef]

23. Cheng, T.; Luo, L.; Yang, L.; Fan, H.; Wu, H. Formation and emission characteristics of ammonium sulfate aerosols in flue gas downstream of selective catalytic reduction. Energy Fuels 2019, 33, 7861-7868. [CrossRef]

24. Reddy, G.K.; He, J.; Thiel, S.W.; Pinto, N.G.; Smirniotis, P.G. Sulfur-tolerant Mn-Ce-Ti sorbents for elemental mercury removal from flue gas: Mechanistic investigation by XPS. J. Phys. Chem. C 2015, 119, 8634-8644. [CrossRef]

25. He, C.; Shen, B.; Li, F. Effects of flue gas components on removal of elemental mercury over Ce-MnO $\mathrm{x} / \mathrm{Ti}-\mathrm{PILCs}$. J. Hazard. Mater. 2016, 304, 10-17. [CrossRef] [PubMed]

26. Zhao, B.; Liu, X.; Zhou, Z.; Shao, H.; Wang, C.; Si, J.; Xu, M. Effect of molybdenum on mercury oxidized by $\mathrm{V}_{2} \mathrm{O}_{5}-\mathrm{MoO}_{3} / \mathrm{TiO}_{2}$ catalysts. Chem. Eng. J. 2014, 253, 508-517. [CrossRef]

27. Lietti, L.; Nova, I.; Ramis, G.; Dall'Acqua, L.; Busca, G.; Giamello, E.; Forzatti, P.; Bregani, F. Characterization and reactivity of $\mathrm{V}_{2} \mathrm{O}_{5}-\mathrm{MoO}_{3} / \mathrm{TiO}_{2}$ De-NOx SCR catalysts. J. Catal. 1999, 187, 419-435. [CrossRef]

28. Xu, Y.; Wu, X.; Lin, Q.; Hu, J.; Ran, R.; Weng, D. $\mathrm{SO}_{2}$ promoted $\mathrm{V}_{2} \mathrm{O}_{5}-\mathrm{MoO}_{3} / \mathrm{TiO}_{2}$ catalyst for $\mathrm{NH}_{3}-\mathrm{SCR}$ of $\mathrm{NO}_{\mathrm{x}}$ at low temperatures. Appl. Catal. A Gen. 2019, 570, 42-50. [CrossRef]

29. Li, L.; Tan, W.; Wei, X.; Fan, Z.; Liu, A.; Guo, K.; Ma, K.; Yu, S.; Ge, C.; Tang, C.; et al. Mo doping as an effective strategy to boost low temperature $\mathrm{NH}_{3}-\mathrm{SCR}$ performance of $\mathrm{CeO}_{2} / \mathrm{TiO}_{2}$ catalysts. Catal. Commun. 2018, 114, 10-14. [CrossRef]

30. Kwon, D.W.; Park, K.H.; Ha, H.P.; Hong, S.C. The role of molybdenum on the enhanced performance and $\mathrm{SO}_{2}$ resistance of V/Mo-Ti catalysts for $\mathrm{NH}_{3}$-SCR. Appl. Surf. Sci. 2019, 481, 1167-1177. [CrossRef]

31. Zhou, Z.; Liu, X.; Liao, Z.; Shao, H.; Hu, Y.; Xu, Y.; Xu, M. A novel low temperature catalyst regenerated from deactivated SCR catalyst for $\mathrm{Hg}^{0}$ oxidation. Chem. Eng. J. 2016, 304, 121-128. [CrossRef]

32. Li, J.; Yan, N.; Qu, Z.; Qiao, S.; Yang, S.; Guo, Y.; Liu, P.; Jia, J. Catalytic oxidation of elemental mercury over the modified catalyst $\mathrm{Mn} / \alpha-\mathrm{Al}_{2} \mathrm{O}_{3}$ at lower temperatures. Environ. Sci. Technol. 2010, 44, 426-431. [CrossRef] [PubMed]

33. Wu, Z.; Jiang, B.; Liu, Y.; Zhao, W.; Guan, B. Experimental study on a low-temperature SCR catalyst based on $\mathrm{MnO}_{\mathrm{x}} / \mathrm{TiO}_{2}$ prepared by sol-gel method. J. Hazard. Mater. 2007, 145, 488-494. [CrossRef] [PubMed]

34. Han, J.; Liang, Y.; Hu, J.; Qin, L.; Street, J.; Lu, Y.; Yu, F. Modeling downdraft biomass gasification process by restricting chemical reaction equilibrium with Aspen Plus. Energy Convers. Manag. 2017, 153, 641-648. [CrossRef]

35. Qin, L.; Xing, F.; Zhao, B.; Chen, W.; Han, J. Reducing polycyclic aromatic hydrocarbon and its mechanism by porous alumina bed material during medical waste incineration. Chemosphere 2018, 212, 200-208. [CrossRef]

36. Chen, W.; Hu, F.; Qin, L.; Han, J.; Zhao, B.; Tu, Y.; Yu, F. Mechanism and performance of the SCR of NO with $\mathrm{NH}_{3}$ over sulfated sintered ore catalyst. Catalysts 2019, 9, 90. [CrossRef]

37. Huang, Z.; Qin, L.; Xu, Z.; Chen, W.; Xing, F.; Han, J. The effects of $\mathrm{Fe}_{2} \mathrm{O}_{3}$ catalyst on the conversion of organic matter and bio-fuel production during pyrolysis of sewage sludge. J. Energy Inst. 2019, 92, 835-842. [CrossRef]

38. Qin, L.; Huang, X.; Zhao, B.; Wang, Y.; Han, J. Iron oxide as a promoter for toluene catalytic oxidation over $\mathrm{Fe}-\mathrm{Mn} / \gamma-\mathrm{Al} 2 \mathrm{O} 3$ catalysts. Catal. Lett. 2019. [CrossRef]

39. Han, J.; Zhang, L.; Zhao, B.; Qin, L.; Wang, Y.; Xing, F. The N-doped activated carbon derived from sugarcane bagasse for $\mathrm{CO}_{2}$ adsorption. Ind. Crop. Prod. 2019, 128, 290-297. [CrossRef]

40. Fan, X.; Li, C.; Zeng, G.; Gao, Z.; Chen, L.; Zhang, W.; Gao, H. Removal of gas-phase element mercury by activated carbon fiber impregnated with $\mathrm{CeO}_{2}$. Energy Fuels 2010, 24, 4250-4254. [CrossRef]

(C) 2020 by the authors. Licensee MDPI, Basel, Switzerland. This article is an open access article distributed under the terms and conditions of the Creative Commons Attribution (CC BY) license (http://creativecommons.org/licenses/by/4.0/). 